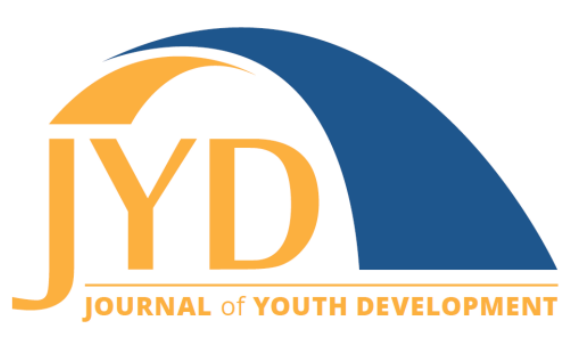

http://jyd. pitt. edu/ | Vol. 14 Issue 2 DOI 10.5195/jyd.2019.763 | ISSN 2325-4017 (online)

\title{
Surrealism is Real
}

\section{Dirdra Medina}

\begin{abstract}
Moving from the Philippines to the United States at a young age to live with a father, with whom you have had limited contact, and meeting a stepmom and stepbrother for the first time provides unique challenges. Socializing and "fitting in" with peers is especially difficult and overwhelming. The youth author highlights how overcoming these obstacles is facilitated through hard work and the support of personal relationships.
\end{abstract}

Key words: immigrant, child's dream, surreal

Just like any typical 7-year old kid, I was so thrilled to hear my dad tell me about his plan to bring me and my sister to the United States. Who wouldn't be? Everyone dreamed that they would be able to come to the United States at least once in their life. It's a great nation, the land of freedom and opportunities. The idea of going and starting a "new life" just seemed unreal, especially if you are the type of person who daydreams a lot. As a result, part of me was thinking that maybe all those things that I felt and heard or saw were just fantasies I made up in order to entertain myself. Be that as it may, it wasn't any fantasy or dream, whatsoever. It was the real deal.

Coming to the United States without my mom and my sister whom I grew up with for eleven years means I will have and will live with new guardians whom I barely know or met. I will live with my dad, whose phone calls, emails and his 2-week visit to the Philippines back when I was in third grade were the only connection I've ever had with him that I remember. I will live with my step family, too (my stepmom and my stepbrother), both of whom I had no close interaction nor even had a long phone conversation with before moving. Their names and their faces that I see from the pictures they sent me are the only things I know so well from them.

(cc) $\mathbf{E Y}$ New articles in this journal are licensed under a Creative Commons Attribution 4.0 License. This journal is published by the University Library System, University of Pittsburgh and is cosponsored by the University of Pittsburgh Press. The Journal of Youth Development is the official peer-reviewed publication of the National Association of Extension 4-H Agents and the National AfterSchool Association. 


\section{Surrealism is Real}

Thus, the fact that I'm going to live with them for the next years of my life was evidently uncomfortable.

Despite being westernized, United States is still a lot different from the Philippines. The people are different, the place is different. It was difficult for me to blend into the crowd. Yes, I am a Filipino, an immigrant, and new, and there were people of many different nationalities, ethnicities, religions, hair color, skin color, eye color, etc. in Texas, which I anticipated. The problem was the fact that I couldn't socialize. I understand and could speak English, however I was self-conscious of the way I spoke the language. Verbally, my grammar was not great. Hence, I couldn't speak freely. In fact, I would go through the long process of forming a sentence in my head, and practice saying it hundreds of times in my head before I could say it out loud. Furthermore, I had low self-esteem. I was not part of a clique, nor did I have a group of close friends to hang out with. I felt so uncool. I am mediocre when it comes to playing and knowing sports. I felt so geeky because all I knew was study, study, and study hard. Being shy is one thing, but lacking self-confidence is different. I couldn't even come near to my extended family whenever we met during our get-togethers.

\section{But that was before.}

I improved myself over time. When people hear my story, they always say that I worked hard, but it wasn't all me. It was also thanks to the people who were by my side, some of whom I met and befriended, that I was able to adapt and be me. I was able to speak up; I became confident. These people understood and accepted me for who I am. They showed me and let me experience many things that even I didn't know that I could do or would be able to do in this lifetime. They advise me, they guide me when they see something is wrong. Up to this day, these people are still here with me to keep me up and running when things get rough.

It has been seven years already. I faced challenges that I didn't think would be huge hurdles to jump until I was placed in front of them. It took me a while, but because of these challenges and help and support I received, I am who I am right now. However, as successful as I think I am, living in the United States still feels surreal to me. "Is this really U.S.? Do I really live here now? Can I really speak English fluently now? Have I really progressed this much? Did I just overcome all of these? This is not a dream, is it?" Those are just some of the questions that I still ask myself whenever I find myself feeling sentimental. No matter how much time has passed, it will take me a really long time to be able to comprehend that these difficulties and extraordinarily unforgettable moments that happened in my life are real. 